\title{
THE PROBLEM OF BOHAI SURYONGS*
}

\author{
ALEXANDER KIM \\ Far Eastern Federal University, School of Education, Department of Historical Education \\ 692525 , t. Ussuriisk, Komsomolskaya st. 44a-11, Russia \\ e-mail:kimaa9@gmail.com
}

Bohai (698-713) was a mediaeval state in East Asia. It was recognised by the Tang Chinese Empire in 713 and became a kingdom from the 760s. However, its status was unclear. Although Bohai was a formal vassal of the Tang Empire, it followed independent policies and regarded itself as an empire, not only in internal policy, but also in its foreign relations. The provincial system of Bohai imitated an imperial system but the status of provincial powers in the Bohai state was not clear. The aim of this paper is to investigate the position of leaders and their influence on the provincial powers of Bohai, and to analyse the specifics of the development of Bohai administration.

Key words: Bohai, East Asia, history, Korean peninsula, suryongs.

The state of Bohai (in Russian: Бохай, in Korean: Parhae 발해, in Chinese: Bohai 渤 海) existed in what is now the Russian Maritime Region (Primorskij kraj / Приморский край), North Korea and Northeastern China from the late 7th to the early 10th centuries AD (Goldobin et al. 1970).

Bohai exerted influence on many states and tribes living close to this state and played a major role in international contacts between Silla, Japan and the Tang Empire. At the same time, Bohai received important cultural influences from other countries, mainly from China, that is why almost all modern Chinese historians consider Bohai a provincial power of the Chinese Empire Tang (Sung 2001; Yao 2001). In many cases Bohai followed the Chinese rituals and diplomatic traditions indeed.

However, for a long time after the establishment of the state, the Bohai rulers could not settle the administrative system in the provinces for several reasons. Firstly, the population of Bohai provinces consisted of Mohe tribes that were, to varying degree, independent of the centre. Secondly, the Bohai rulers did not have their own

${ }^{*}$ This article has been prepared with the support of the Korea Foundation. 
system of governing the different districts, mainly because they had not needed this skill before. And thirdly, Bohai did not have many districts which could be called provinces.

But during the reign of the third Bohai ruler Da Jinmao (737-793, in Chinese - 大欽茂, in Korean - 대흠무) a far-sighted foreign policy began to be formed. At that time the Tang Empire had internal problems, therefore Bohai made use of this favourable situation, and pursued expansionistic foreign policy in the eastern and northern directions by conquering vast stretches of lands. Numerous Mohe tribes, former vassals of the Tang Empire, got under the suzerainty of Bohai.

After 762 (when Da Jinmao received the status of king from the Tang Empire), some Bohai officers, who held ranks in the provincial administration of Bohai, started to come to Japan as members of ambassadorial missions (Song Ki-ho 1995, p. 108).

According to the ancient Chinese political system, an empire always had vassals that had to receive their investiture from the suzerain. The Bohai ruler regarded certain parts of his aristocracy as vassals. In the opinion of Song Ki-ho (1995), suryongs might have been vassals of the Bohai ruler. As stated in Korean and Chinese annals, suryongs (in Chinese - 首領, in Korean - 수령) took part in the political activity of the Bohai state. However, in Korean mediaeval history suryongs were the heads of villages. But in Bohai, according to the opinion of Song Ki-ho, suryongs were the chiefs of the dependent vassal tribes that lacked official status. Almost all of them were leaders of the Mohe tribes (Song Ki-ho 1995, pp. 196-197). It seems likely that Korean suryongs were the tribal chiefs in ancient times, but in the process of centralisation of the Korean Peninsula they lost real power and became heads of villages.

However, we believe that the suryong system in Bohai was established not during the reign of Da Jinmao. As is known, Bohai had several territorial expansions in different times under different rulers, first under Da Zuorong, 大祚榮, 698-719, then Da Wuyi, 大武藝, 719-738, Da Jingmao, 大欽茂, 738-794, Da Renxiu, 大仁 秀, 818-830 and Da Yizhen, 大絭震, 830-857 (Shavkunov et al. 1994; Kradin 2005) (see Appendix 2). Clearly, the Bohai rulers used the system of suryongs for establishing contacts with the leaders of conquered tribes and groups. It must be noted that most scholars received information about the Bohai suryongs from Chinese and Japanese annals, although Chinese and Japanese officials at that time did not dispose of exact information about Bohai.

In contacts with suryongs, Bohai imitated the relations between the Tang Empire and its vassal tribes and rulers of the dependent states. But contacts between Bohai and the suryongs must not be regarded as relations between suzerain and vassals, as was the case in the Chinese Empire. At first, the positions held by suryongs in Bohai were unclear. In the opinion of the Japanese scholar Suzuki Yasutami, suryongs in the Bohai state were people who occupied a position between high-rank officials and commoners. Therefore, suryongs were an important reserve for Bohai administration. Suryongs originated from the old tribal aristocracy that depended on Bohai. The Japanese scholar noted that in 841 a Bohai ambassadorial mission arrived in Japan and part of this mission included 65 great suryongs (대 수령) from all Bohai regions (Bohai consisted of 65 regions) (Suzuki 1996). 
By territorial expansion the Bohai rulers acquired new territories and dependent tribes. Certainly, the number of suryongs increased. In the opinion of Song Ki-ho, Bohai suryongs had internal independent activity, and many of them had differing ranks from the Bohai officials. Moreover, Bohai suryongs took part in the diplomatic activity of the Bohai state, for example, they were members of Bohai ambassadorial missions to Japan. Probably, the political activity pursued by suryongs in foreign and internal policy was not limited to these actions only.

Korean and Japanese scholars think that the suryongs (수령; 首領) were an important reserve for Bohai officials. They were elected from tribal leaders who were dependent on the Bohai state. The position and role of the suryongs was very interesting, one may claim even two-faced. On the one hand, they were a part of a lord and vassal system for Bohai. Suryongs were obliged to pay tribute to the Bohai government and receive gifts from Bohai rulers in return. But on the other hand, sometimes suryongs were a centre for resistance and separatism against Bohai, when the state had problems. Sometimes suryongs immigrated to other countries, for example, to Japan in 810 .

Bohai officials, who arrived in the provinces from the capital, were commanders of the suryongs but did not take part in their internal activity. So, Bohai suryongs had independence in domestic policy, but had to pay taxes to the Bohai state (Song Ki-ho 1995, p. 228; Parhaesa 1996, pp. 4-5). Therefore we can conclude that the Mohe tribes, who had vassal relations with Bohai, did not depend on Bohai officials directly. The suryongs occupied a position between Bohai officials and commoners of the Mohe tribes (Parhaesa 1996, p. 8).

Chinese and Japanese written sources provide information that some Bohai suryongs were trained in China and were members of Bohai groups accompanying students who had passed exams in the Tang Empire. Probably, the suryongs were members of suwei 宿衛, the imperial guard of the Tang Empire, who protected the imperial palace (Song Ki-ho 1995, pp. 164-165). These troops consisted of members of the aristocracy from other states and large tribes that had vassal relations with the Chinese Empire (Ivliev 2005).

It should be noted that suryongs were presumably not members of the first Bohai ambassadorial missions to Japan. (One could argue against this that Japanese chroniclers, as a rule, wrote only the names and ranks of the ambassador and his deputies. In the case of the Bohai missions they certainly did not write the names of all members of the mission, so it is not excluded that Bohai suryongs could have been part of the ambassadorial group.) Song Ki-ho considered this matter from another perspective; he claims that in the initial period of contacts between the two states, the status of Japan was considerably higher than that of Bohai. Only in the 760s, when Da Jinmao received a new rank, did he start to send suryongs as members of ambassadorial missions to Japan (Song Ki-ho 1999). Probably, Bohai could not send suryongs to Japan earlier than it received the status of kingdom, because Japan would have considered this a political insult.

As shown above, information about Bohai suryongs is inconsistent. On the one hand, in many cases Bohai suryongs can be regarded as provincial leaders, but 
on the other hand, suryongs were part of the Bohai aristocracy, trained in China and Japan as members of ambassadorial missions, and could also be members of suwei in the Tang Empire, although suwei consisted only of aristocrats of high rank.

It is likely that Bohai suryongs consisted of different categories of provincial officials and chiefs of various tribes. Moreover, these tribes had different statuses, and the suryong system survived the destruction of the Bohai state. If suryongs had been only Bohai provincial officers, they could not have existed after 926 . This fact confirms that the system of Bohai suryongs had two bases: (1) the provincial system of the Bohai state, and (2) the local system of tribal government. The second basis will be discussed below, in the section on the position of suryongs after the destruction of Bohai.

As mentioned above, information collected by different scholars about Bohai suryongs is inconsistent. Therefore we can guess that Bohai suryongs included some groups of leaders with different ranks and did not have relations with each other in different fields of activity.

The first group consisted of chiefs of dependent or vassal tribes. Certainly, the largest number of suryongs was in this category. Almost all of them originated from the Mohe groups. The Bohai officials who arrived from the capitals and served in provinces could govern them. The suryong group was the most restless, but at the same time the most necessary part of the structure of the Bohai state. When there was a power crisis in Bohai, these suryongs provided a local base for separatist tendencies, therefore some distant provinces often separated from the state. But on the other hand, in the period of state stability, these suryongs paid taxes, supported trade relations between the centre and the periphery, sent military troops to the Bohai army for foreign expansion. After Bohai was destroyed in 926, the eastern part of the state became independent. A large number of suryongs lived in these areas.

It is likely that this group of suryongs included the chiefs from dependent tribes, but they had a different political status. As is known, Bohai ambassadorial missions were trained for the Turkic Khaganate and Japan, and members of these groups were leaders from different tribes such as Heishui Mohe and Te-li.

The second group of suryongs consisted of the provincial officials of Bohai. The South Korean scholar Lim Sang Seon noted that in Chinese and Japanese records about Bohai there was no information about the heads of districts. Therefore he believed that the suryongs were the heads of these small territorial units (Lim 1990). Suryongs from the first group could not have been the heads of these districts because the Bohai state structure included many provinces in the central and other parts of the state which did not have dependent tribes.

The third group consisted of great suryongs (Da Suryongs). As mentioned above, in 841 a Bohai ambassadorial mission arrived in Japan. The group consisted of 65 great suryongs, one from each region in Bohai. They were neither non-provincial officers of lower ranks nor the chiefs of dependent tribes. From the available evidence it is likely that they were Bohai aristocrats or officials with high-level ranks. They were members of the Bohai ambassadorial groups and the Chinese imperial guard troops. Therefore, the great suryong can be regarded as an aristocratic title in Bohai. 
As shown above, Bohai suryongs were divided into three main groups of leaders, who had different ranks, positions and possibilities. The suryongs consisted of aristocrats, provincial officials and chiefs of different tribes. It is clear that the system of suryongs was influenced by the political structure of the Tang Empire, but an original component also appears in the suryong system in Bohai. For example, the Chinese state did not have a system of rank or hierarchy as highly developed as the suryong system. Moreover, this system survived after Bohai had been destroyed, as will be demonstrated below in the case of Dae Nan Ha. It can be argued that the system of suryongs gained its dominant influence from Mohe tribes, because the chiefs of these tribes consisted of the first group of suryongs. Probably, the tribal chiefs changed the Chinese system of the suzerain-vassal relationship according to their understanding of dependence. Certainly, the policy of decentralisation played an essential role in this process in Bohai. Controversial relations between the centre and peripheries of a state existed not only in Bohai. Some elements of this system can be obsereved in Japan, as well as in Silla, during the same period.

In conclusion, although Bohai governors had formal vassal relations with the Chinese Empire and held positions as dependent rulers, and as kings in foreign relations during the 8th century, in internal policy, Bohai governors used their imperial status to support their positions during periods of stability and crisis in the Tang Empire. Moreover, sometimes they tried to support their imperial status in foreign relations, for example, with Japan (Matveev 1929; Kim 2009, 2011). So obviously enough, Bohai alternated the use of its royal and imperial status depending on the situation.

A similar system was used by other states that were neighbours of the Tang Empire; they used it within state structures that were equivalent to Chinese imperial models, but in foreign relations they held a hierarchical subordination to the Chinese Empire.

This system of using imperial status and an independent political institution for domestic reign also survived the destruction of Bohai. After 929 the Bohai people formed part of the population of established states Dingan and Sin Liao; the rulers of these states used independent structures to govern their countries. In 1116, Bohai general Gao Yunchan, who served in the Khitan state, rebelled against the Liao Empire and announced a new state, the Great Bohai state. He used the same independent political institution of government and considered himself Emperor (Parhaesa 1996; Song 1995, pp. 178-179). This example clearly shows that the Bohai people, after the destruction of their state, still remembered their previous imperial status. Moreover, the suryong system existed for a long time after 926 and it is likely that after 926 it contained all elements of the three groups. For example, in 979 the Bohai suryong Dae Nan Ha immigrated with 300 warriors from the Liao Empire to Koryǒ. In the spring of 984 the Koryǒ king invited him to his court. Dae Nan Ha very successfully fought against "barbarian" tribes (probably, Mohe groups, who had arrived in areas of the former Bohai state), so after this victory he received an invitation to go for hunting with the king who gave him alcohol and a substantial amount of money $(100,000$ coins) (Yu Dyuk-gong 2000, p. 100). 
It is noteworthy that Dae was the family name of the Bohai dynasty. Clearly, if a suryong was a person from the provincial aristocracy of officials, he could not have had the king's family name. And men from the Bohai royal family could not have been the head of a village or a provincial tribe.

But it must also be borne in mind that by this time Koryǒ officials did not know the specifics of the Bohai social system and almost none of them had precise information on Bohai. They must have adopted the Bohai ranks for the Koryor official system. In this case, Koryor officials could have regarded certain ranks of the Bohai aristocracy as suryongs, but Dae Nan Ha was the commander of military troops, had an audience with the Koryǒ king and received awards from the king (Yu Dyuk-gong 2000, pp. 100-101). This would have been impossible for Korean suryongs who were merely heads of villages.

In our opinion, Koryǒ officials could not have regarded the Bohai aristocracy as suryongs in the Koryǒ context. In the case of Dae Nan Ha, we can see many differences between his position and that of the Korean suryongs. One can reason that Koryǒ officials ranked Dae Nan Ha not as a Koryǒ suryong, but as a Bohai suryong. In conclusion, the position held by Bohai suryongs was very different from those held by Koryǒ suryongs. Although Koryǒ nobles had pieces of information about the ranks of the Bohai society, but, despite the fact that sometimes common names occurred, they interpreted these ranks in a different way from those in Koryǒ and other countries. Bohai suryongs were part of the aristocracy, but Korean suryongs were only leaders of commoners and could not belong to the aristocracy. To my mind, Koryǒ suryongs were chiefs of various tribes in the period of Koguryǒ, Paekche and Silla, the so-called Samguksidae (삼국시대, Period of Three states). But in the process of centralisation they lost their privileges and positions, and became merely heads of villages. Certainly, the process of transformation of a tribal chief into a head of village took much time, presumably, more than a couple of centuries.

Evidently, Dae Nan Ha was a member of Bohai aristocracy. So, on the basis of information about his troop and his position, two conclusions can be drawn. Firstly, the category of Bohai suryongs was wider than Korean scholars have hitherto believed, and included members of Bohai aristocracy such as leaders from the royal dynasty in the former Bohai state (Dae was a name of the ruling dynasty of that state). Secondly, after the destruction of Bohai, there was no central power in the eastern provinces of this state, and Bohai aristocrats, who fled from the Khitan army to the eastern part of the state, joined the suryongs.

Finally, the number of warriors of this Bohai suryong system must be touched upon. From a detailed examination of the records of the Korean mediaeval chronicle "Koryǒ sa", it is evident that Bohai people made an orderly departure from the areas of the former Bohai state or Dongdan to the Koryǒ kingdom in groups of 100, 300, or 1000 persons or multiple numbers. Moreover, the "Koryǒ sa" shows that this process continued not only for several years, but more than a century (see Appendix 1) (Han 1994).

It is possible to compare the number of people in these Bohai troops with the Jurchen system of men'an and mouke. The noted Russian scholar M. V. Vorob'ev 
translated the Jurchen annals "Jin shi" and wrote that men'an consisted of 1000 households and were required to send men to an army group that included 1000 warriors, but mouke, depending on geographical conditions and different time periods, consisted of 100-300 households and had to send men to the army military troops that included 100-300 soldiers (Vorob'ev 1975). Accordingly, the number of soldiers in the group led by Dae Nan Ha was close to the number of soldiers in mouke. Probably, he was one of the suryongs who were heads of military troops of mouke. Some Bohai suryongs with their people might have united to organise large groups for immigration to the territory of the Koryor Kingdom. As is known, mouke had two leaders, the head of community and the head of the military troop. As one person could occupy two positions, it is not possible to draw conclusions about the exact position occupied by suryongs in this system. It is possible that the head of men 'an could have been elected from the suryongs if he had a good reputation and strong military troops. In the 12 th century the situation changed: three Jurchen households in mouke sent one warrior to the army in the period of the Jin Empire.

As is known, the Jurchen were descendants of the Heishui Mohe who lived at the periphery of the Bohai state and remained there for a long time under the influence of Bohai culture. Therefore it is quite clear why the institution of suryongs exerted an important influence on Jurchen society. In sum: the social system of Jurchen men'an and mouke was part of the provincial structure of the Bohai state.

\section{Appendix 1}

Information about the organised migrations of Bohai people to Koryo ${ }^{1}$

\begin{tabular}{|l|c|l|}
\hline \multicolumn{2}{|c|}{ Date } & \multicolumn{1}{c|}{ Events } \\
\hline $\begin{array}{l}\text { 6th day 9th month } \\
\text { 8th year of Thaejo }\end{array}$ & 925 & $\begin{array}{l}\text { Bohai general Sin Dok with 500 people fled to } \\
\text { Koryó }\end{array}$ \\
\hline $\begin{array}{l}\text { 16th day 9th month } \\
\text { 8th year of Thaejo }\end{array}$ & 925 & $\begin{array}{l}\text { Bohai officials Dae Hwa Gyun, Dae Gyun Go, Dae } \\
\text { Wong Gyun, Dae Bok Mo, Dae Sim Lee with 100 } \\
\text { households emigrated to Koryó }\end{array}$ \\
\hline $\begin{array}{l}\text { 29th day 12th month } \\
\text { 8th year of Thaejo }\end{array}$ & 925 & $\begin{array}{l}\text { Bohai officials Mo Doo Gan and Park O with 1000 } \\
\text { households emigrated to Koryǒ }\end{array}$ \\
\hline $\begin{array}{l}\text { 3rd day 3rd month } \\
\text { 10th year of Thaejo }\end{array}$ & 927 & $\begin{array}{l}\text { The head of Deparment of Social Work O Hying } \\
\text { with 50 Bohai people (according to other records: } \\
\text { 5000 people) fled to Koryǒ }\end{array}$ \\
\hline $\begin{array}{l}\text { 24th day 6th month } \\
\text { 12th year of Thaejo }\end{array}$ & 929 & $\begin{array}{l}\text { Bohai official Hong Gyong and “others" in 20 ships } \\
\text { with people and property fled to Koryǒ }\end{array}$ \\
\hline
\end{tabular}

${ }^{1}$ The names of almost all the Bohai people were written in Korean writing. 


\begin{tabular}{|l|c|l|}
\hline $\begin{array}{l}\text { 10th day 9th month } \\
\text { 12th year of Thaejo }\end{array}$ & $\begin{array}{l}\text { Bohai official Jong Gyin with more than 300 people } \\
\text { arrived by land in Koryǒ }\end{array}$ \\
\hline 17th year of Thaejo & 934 & $\begin{array}{l}\text { Bohai crown prince Da Guainsian (in Korean Dae } \\
\text { Kwang-heon) emigrated with a few thousand people } \\
\text { (or households) to Koryǒ. The Koryó king gave him } \\
\text { the family name Wang Ji and 4th rank Wonbo, and } \\
\text { registered his name in the lists of the royal clan. } \\
\text { He became the governor of Baijou (Paekju). His } \\
\text { officials received ranks, Bohai soldiers received } \\
\text { lands and houses }\end{array}$ \\
\hline 21st year of Thaejo & 938 & $\begin{array}{l}\text { Bohai official Park Sying with 3000 households } \\
\text { arrived in Koryǒ }\end{array}$ \\
\hline 4th year of Kyongjon & 979 & $\begin{array}{l}\text { Bohai suryong Dae Nan Ha with 300 warriors fled } \\
\text { to Koryǒ }\end{array}$ \\
\hline $\begin{array}{l}\text { 10th month 21st } \\
\text { year of Hyeonjong }\end{array}$ & 1030 & \begin{tabular}{l} 
500 Bohai people fled to Koryǒ \\
\hline
\end{tabular} \\
\hline
\end{tabular}

\section{Appendix 2}

\section{Bohai rulers}

1. Da Zuorong (大祚榮), 698-719

2. Da Wuyi (大武藝), 719-737

3. Da Qinmao (大欽茂), 737-793

4. Da Yuanyi (大元義), 793-794

5. Da Huayu (大華與), 794-795

6. Da Sonlin (大嵩璘), 795-809

7. Da Yuanyu (大元瑜), 809-812

8. Da Yanyi (大言義), 812-817
9. Da Mingzhong (大明忠), 817-818

10. Da Renxiu (大仁秀), 818-830

11. Da Yizhen (大彝震) , 830-857

12. Da Qianhuang (大虔晃), 857-872

13. Da Xuanxi (大玄錫), 872-894

14. Da Weixie (大瑋瑎), 894-907(?)

15. Da Yinzhuan (大諲譔), 907(?)-926

\section{Bibliography}

Goldobin, A. M. et al. (eds) (1970): Istoriia stran zarubezhnoj Azii v srednie veka. Moscow, Nauka. Han Giu-cheol 한규철 / 韓圭哲 (1994): Parhaeǔi taekwankaesa 발해대관계사 [The history of Bohai foreign policy relations]. Seoul, Tosochulban sinsovon.

Ivliev, A. L. (2005): Ocherk istorii Bohaja. In: Andreeva, V. Zh. (ed.): Rossijskij Dal'nij Vostok $v$ drevnosti i srednevekov'e: otkrytija, problemy, gipotezy. Vladivostok, Dal'nauka, pp. $449-475$.

Kim, A. A. (2009): Plan sovmestnogo napadenija Bohaja i Japonii protiv Silla. Russia and the Pacific No. 2, pp. 70-73. 
Kim, A. A. (2011): Istorija gosudarstva Boha. Ussurijsk, Primorskaja Gosudarstvennaja sel'skohozjajstvennaja Akademija.

Kradin, N. N. (2005): Stanovlenie i êvoljucija srednevekovoj gosudarstvennosti. In: Andreeva, Zh. V. (ed.): Rossijskij Dal'nij Vostok v drevnosti i srednevekov'e: otkrytija, problemy, gipotezy. Vladivostok, Dal'nauka, pp. 439-448.

Lim Sang-seon 임상선 / 林相先 (1990): Parhaesayi ihje 발해사의이해 [Understanding Bohai history]. Seoul, Tosochulphansinsowon.

Matveev, Z. N. (1929): Bohaj. Raboty Dal'nevostochnogo Gosudarstvennogo Universiteta. Series 6, No. 8. Vladivostok, Dal'nevostochnyj Gosudarstvennyj Universitet.

Parhaesa (1996): Song Ki-ho 송기호 / 宋基豪-Han Gju-chǒl 한규철 / 韓圭哲-Lim Sang-seon 임상선 / 林相先 (eds): Parhaesa 발해사 [The history of Bohai] (Hanguksa vol. 10). Seoul, Kuksapǒnchanwiwonhwae.

Shavkunov, E. V. et al. (eds) (1994): Gosudarstvo Bohaj (698-926) i plemena Dal'nego Vostoka Rossii. Moscow, Nauka.

Song Ki-ho 송기호 / 宋基豪 (1995): Parhae jeongchiyeoksa yeongu 발해정치역사연구 [The study of Bohai political history]. Seoul, Ilchokal.

Song Ki-ho 송기호 / 宋基豪 (1999): Parhaereul tasi ponda 발해를 다시 본다 [Considering Bohai again]. Seoul, Tosochulpanjuryeoseon.

Song Kiho (2001): On the Nature of the "Sureong" in Parhae. In: Artem'ev, A. R. (ed.): Drevnjaja $i$ srednevekovaja istorija Vostochnoj Azii. K 1300-letiju obrazovanija gosudarstva Bohaj. Vladivostok, Dal'nevostochnoe otdelenie Rossijskoj Akademii nauk, pp. 119-125.

Sung Hong (Сунь Хоун) (2001): Mohe, Bohaj i chzhurchzhjeni. In: Artem'ev, A. R. (ed.): Drevnjaja i srednevekovaja istorija Vostochnoj Azii. K 1300-letiju obrazovanija gosudarstva Bohaj. Vladivostok, Dal'nevostochnoe otdelenie Rossijskoj Akademii nauk, pp. 80-89.

Suzuki Yasutami (1996): Chieftain System in Bohai. In: Shavkunov, E. V. (ed.): The First International Symposium of Bohai Culture. Vladivostok, Dal'nevostochnoe otdelenie Rossijskoj Akademii nauk, pp. 3-7.

Vorob'ev, M. V. (1975): Chzhurchzhjeni i gosudarstvo Czin' (X-1234). Moscow, Nauka.

Yao Feng (Яо Фенг) (2001): Politika nacional'noj avtonomii imperii Tan v otnoshenii Bohaja. In: Artem'ev, A. R. (ed.): Drevnjaja i srednevekovaja istorija Vostochnoj Azii. K 1300-letiju obrazovanija gosudarstva Bohaj. Vladivostok, Dal'nevostochnoe otdelenie Rossijskoj Akademii nauk, pp. 90-97.

Yu Dyuk-gong 유득공 / 柳得恭 (2000): Parhae go 발해고 [The study of Bohai]. Seoul, Hangukjonchǒnso. 